Zbl. Bakt. 274, 471-474 (1991)

(c) Gustav Fischer Verlag, Stuttgart/New York

\title{
Legiolysin, a New Hemolysin from L. pneumophila
}

\author{
URSULA RDEST, EVA WINTERMEYER, BIRGIT LUDWIG, \\ and JÖRG HACKER
}

Institut für Genetik und Mikrobiologie, Universität, D-8700 Würzburg

With 2 Figures - Received June 21, 1990 - Accepted in revised form August 17, 1990

\section{Summary}

Legionella pneumophila generates exotoxins, cytolysins, proteases or hemolysins that damage host cells like erythrocytes or tissue culture cells. The gene for a new $L$. pneumophila hemolysin without a proteolytic activity was identified, cloned in E. coli and sequenced. The gene product was analysed by SDS-Polyacrylamide-gel-electrophoresis.

\section{Zusammenfassung}

Legionella pneumophila bildet Exotoxine, Zytolysine, Proteasen oder Hämolysine, die Wirtszellen wie Erythrozyten oder Animalzellen schädigen. Das Gen für ein neues $L$. pneumophila Hämolysin ohne proteolytische Aktivität wurde identifiziert, in E. coli kloniert und sequenziert. Das Genprodukt wurde durch SDS-Gelelektrophorese analysiert.

Legionella pneumophila is a Gram-negative, aerobic inhabitant of freshwater and soil environments. It is also a facultative intracellular pathogen that invades and grows in human alveolar macrophages leading to acute bronchopneumonia referred to as legionellosis. The cytopathology of infected lung tissue suggests involvement of extracellular proteolytic enzymes or toxins in the pathogenesis of the disease.

A L. pneumophila zinc metallo-protease has been characterized as a protein of 38 $\mathrm{kDa}(5)$, the sequence of the structural gene was found to possess a single large open reading frame (ORF) of 1,629 nucleotides (1). The protease exhibits a hemolytic effect on canine but not on human erythrocytes and a cytotoxic effect on chinese hamster ovary cells $(\mathrm{CHO})$ :

We describe here a new hemolysin called legiolysin (Lly) which lyses erythrocytes from man, guinea-pig and dog and exhibits no proteolytic activity. In order to screen for the gene involved in the production of legiolysin, we constructed a gene library of the L. pneumophila genome. Total DNA of L. pneumophila was cleaved partially with Sau $3 \mathrm{~A}$ and cloned into the BamHI-cut cosmid vector pLAFR2 (2) and transduced into E. coli HB 101. 2885 clones were tested for hemolytic activity on blood agar plates 


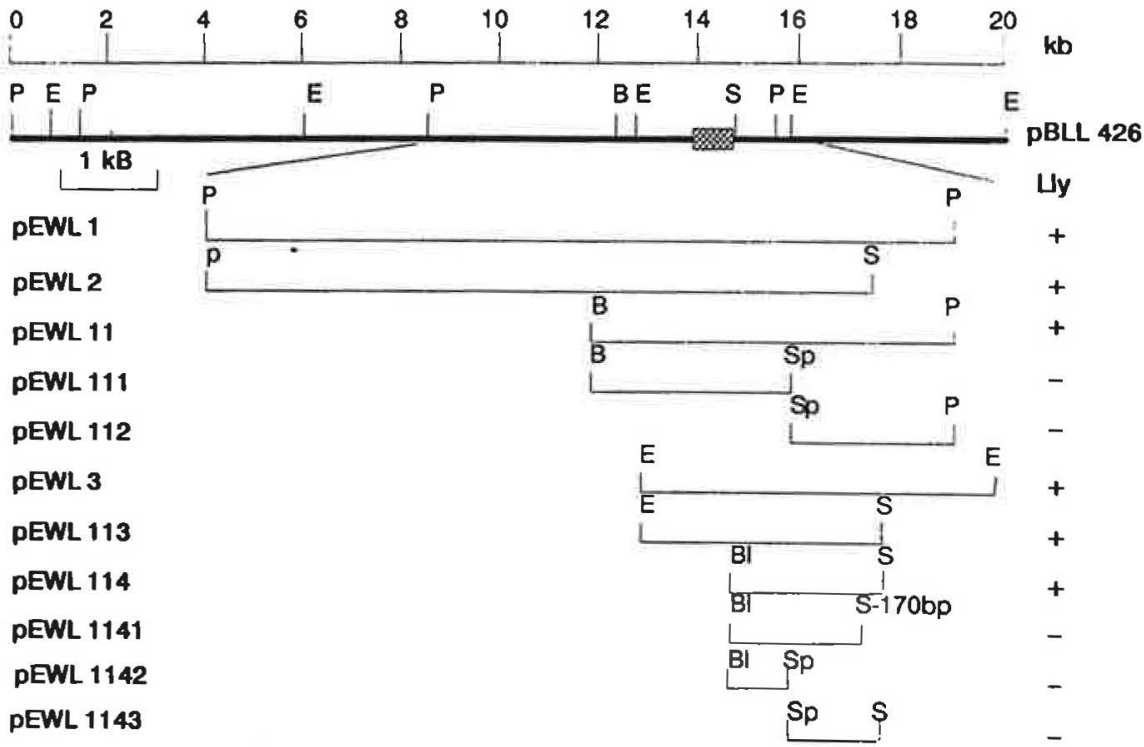

Fig. 1. Restriction map of the chromosome region containing the legiolysin gene from $L$. pneumophila. The restriction fragments contained within the various subclones are indicated. The subclones exhibiting hemolytic activity are marked Lly+, non-hemolytic clones are marked Lly-. The restriction sites are: $\mathrm{B}=\mathrm{BamHI} ; \mathrm{Bl}=\mathrm{BalI}$; $\mathrm{E}=\mathrm{EcoRI}$; P = PstI; $\mathrm{S}=$ SmaI; Sp $=$ SphI.

containing human erythrocytes and proteolytic activity on skim milk plates. Eight clones produced a hemolytic lysis zone but had no proteolytic activity. Eleven clones caused proteolysis but no hemolytic effect on human erythrocytes.

The hemolytic and non-proteolytic clone pBLL426 was used for further analysis of the legiolysin determinant. The Legionella DNA insert of pBLL426 was used as a gene probe in Southern hybridization (6) of the eight hemolytic and the eleven proteolytic clones and of total DNA of L. pneumophila. The DNA from the proteolytic clones did not hybridize, the DNA from the hemolytic clones and total Legionella DNA showed one band of hybridization indicating that the lly gene is present only once on the Legionella genome.

Clone pBLL426 was used to establish a restriction map (Fig. 1). Different DNA fragments were ligated into the vector puC19 (7) and the subclones were analysed for hemolysin production. A $6.7 \mathrm{~kb}$ PstI fragment located in pEWL1 confered the hemolytic phenotype. The hemolysin specific gene seems to be transcribed from its own promoter since hemolysin production occured after subcloning in both orientations. To identify the hemolysin specific gene from a $4.2 \mathrm{~kb} \mathrm{BamHI-PstI} \mathrm{insert} \mathrm{in} \mathrm{plasmid}$ pEWL11 a set of in vitro deletion mutants was constructed. These data show that the hemolysin specific gene must be located between coordinates 13 and 15 in Fig. 1. The smallest insert still coding for hemolysis is a BalI-SmaI fragment in plasmid pEWL114. A comparison to the restriction map of the protease gene established by Quinn et al. (5) revealed a completely different restriction pattern. 


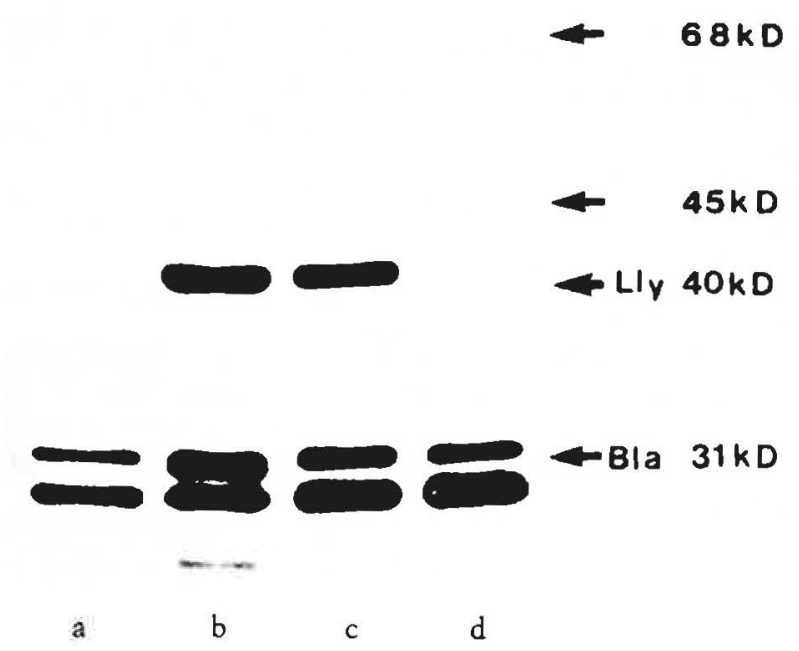

Fig. 2. Gene products identified in minicells of $\mathrm{E}$. coli which are determined by recombinant plasmids carrying BamHI-PstI, BalI-SmaI or BalI-ExoIII-fragments from the Lly-region of the L. pneumophila chromosome. a) ${ }^{35}$ S-labeled proteins determined by vector plasmid pUC19 as a control, Bla is $\beta$-Lactamase, b) pEWL11, c) pEWL114, d) pEWL1141.

In order to analyze the protein encoded by the legiolysin specific gene, minicells (4) were isolated from strain P678-54 pEWL11, P678-54 ${ }^{\circ} \mathrm{pEWL} 114$ and P678-54 $\mathrm{pEWL1141}$ and as a vector control from P678-54 pUC19. The purified minicells were radiolabeled with ${ }^{35} \mathrm{~S}$-Methionine, lysed in loading buffer according to Laemmli (3) and the proteins of the lysate were separated on a $12 \%$ SDS-PAGE (Fig. 2). The hemolytic clones pEWL11 and pEWL114 expressed a protein of a molecular weight of $40 \mathrm{kDa}$, the non-hemolytic clone $\mathrm{pEWL1141}$, where the gene is truncated from the 3 'end (Fig. 1), did not show an additional band besides the vector bands.

To characterise the $l l y$ gene more precisely we have sequenced the corresponding DNA region of about 1000 basepairs (data not shown). There is no homology to the sequence of the protease gene determined by Quinn et al. (5). An open reading frame of $813 \mathrm{bp}$ was found for lly which could code for a protein of a total of 270 amino acids, corresponding to a molecular mass of $29 \mathrm{kD}$. The molecular weight of the legiolysin protein determined from the SDS-PAGE differs from the size predicted for legiolysin from the ORF of the DNA sequence. This discrepancy can be due to unusual mobility of the protein in the gel system or to post-translational modification of the protein.

\section{References}

1. Black, W. J., F. D. Quinn, and L. S. Tompkins: Legionella pneumophila Zinc Metalloprotease is structurally and functionally homologous to Pseudomonas aeeruginosa Elastase. J. Bact. 172 (1990) 2608-2613

2. Knapp, S. and J. Mekalanos: Two trans-acting regulatory genes (vir and mod) control antigenic modulation in Bordetella pertussis. J. Bact. 170 (1988) 5059-5066 
3. Laemmli, U. K.: Cleavage of structural proteins during the assembly of the head of Bacteriophage T4. Nature 227 (1970) 680-685

4. Noegel, A., U. Rdest, W. Springer, and W. Goebel: Plasmid cistrons controlling synthesis and excretion of the exotoxin haemolysin of Escherichia coli. Molec. gen. Genet. 175 (1979) 343-350

5. Quinn, F. D. and L. S. Tompkins: Analysis of a cloned sequence of Legionella pneumophila encoding a $38 \mathrm{kD}$ metalloprotease possessing haemolytic and cytotoxic activities. Molec. Microbiol. 3 (1989) 797-805

6. Southern, E. M.: Detection of specific sequences among DNA fragments separated by gel electrophoresis. J. Molec. Biol. 98 (1975) 503-517

7. Vieira, $I$. and $J$. Messing: The pUC plasmids, an M $13 \mathrm{mp} 7$-derived system for insertion mutagenesis and sequencing with synthetic universal primers. Gene 19 (1982) 259-268

Dr. Ursula Rdest, Institut für Genetik und Mikrobiologie der Universität, Röntgenring 11, D-8700 Würzburg 